André Kwak

\section{ENTREATO PROGRESSISTA NA OCUPAÇÃO DO ESPAÇO PÚBLICO NA CIDAde DE SÃO Paulo}

I 2

is

\title{
RESUMO
}

A cidade de São Paulo experimentou um entreato progressista que confrontou sua matriz rodoviarista e seu histórico de negação dos espaços públicos, introduzindo políticas públicas que enfrentaram esse status quo vigente. Nesse breve período entre 2013 e 2016, implementaram-se políticas estruturantes e ações específicas que dialogavam com um paradigma contemporâneo na produção e ocupação de áreas públicas, tendo como ideário uma cidade mais inclusiva e democrática, com a ativação do urbano para o lazer, esporte e cultura. Por meio desse enfrentamento, foi possível um reordenamento do viário, equilibrando de forma racional e mais democrática sua utilização, que passou a acomodar, numa equação menos desigual, o transporte coletivo e o individual não motorizado. Outro importante pilar dessa gestão caracterizou-se pela alocação dos investimentos públicos municipais: equipamentos e infraestruturas de vulto foram realizados majoritariamente nas regiões mais carentes da cidade, indo na contracorrente histórica de investimentos no centro expandido. Essas ações se mostraram de grande relevância pelo efeito catalisador na ativação dos espaços públicos da cidade, dando enorme dinamismo social associado à mudança do foco das políticas públicas urbanas do automóvel para o pedestre. Ao mesmo tempo, a cidade presenciou a propagação de inflamado debate entre grupos sociais de diversos matizes, muitas vezes antagônicos, transformando a cidade em uma arena de disputas, com cada intervenção urbana sendo disputada palmo a palmo, numa complexa rede de atores sociais e institucionais com seus respectivos interesses, tendo a utilização (ou não utilização) do espaço público como "prêmio" desses embates, que se deram em inúmeras rodadas de deliberação democrática.

\section{Palavras-chave}

Mobilidade urbana. Espaço público. Planejamento urbano. Grupos de interesse. Infraestrutura. 


\section{A PROGRESSIST ENTR'ACTE IN THE OCCUPATION OF PUBLIC SPACE IN THE CITY OF SÃO PAULO}

\section{ABSTRACT}

The city of São Paulo has experienced a progressist entr'acte that confronted its roadway matrix and its history of public space denial by introducing public policies that have faced this actual status quo. In the brief period between 2013 and 2016, structuring policies and specific actions were implemented to dialogue with the contemporary paradigm in the production and occupation of public areas, idealizing a more inclusive and democratic city, activating the urban space for leisure, sport and culture. Through this confrontation, a reorganization of the roadway system became possible by balancing its use more rationally and democratically to accommodate, in a less unequal equation, the collective transport and the non-motorized individual one. Another important pillar of this administration was characterized by the allocation of municipal public investments: facilities and major infrastructures were implemented in the neediest regions of the city, going against the historical countercurrent of investments in the expanded center. These actions proved to be greatly relevant due to the catalyzing effect while activating the city's public spaces, granting social dynamism associated to the shift of urban public policies from automobile to pedestrian. At the same time, the city has experienced an increasing and inflamed debate among social groups of various trends, often antagonistic, transforming the city into an arena of disputes, with each urban intervention being argued by a complex network of social and institutional actors with their respective interests, and the use (or non-use) of the public space considered a "prize" for these discussions, which took place in numerous rounds of democratic deliberation.

\section{KEYWORDS}

Urban mobility. Public place. Urban planning. Interest groups. Infrastructure. 


\section{ENFRENTANDO O STATUS QUO RODOVIARISTA: POLÍTICAS URBANAS PARA O PEDESTRE E O DIREITO À CIDADE}

O processo de formação do urbano na cidade de São Paulo foi marcado pela segregação socioespacial e pela falta de infraestrutura nas periferias, com famílias limitadas à cidade informal ${ }^{1}$ e alijadas do Direito à Cidade $^{2}$. Isso se deveu, ora pelos processos de gentrificação e especulação imobiliária característicos da produção do espaço no capitalismo, que exercem pressão sobre o preço da terra urbanizada, tornando seu acesso um privilégio dos mais ricos, ora pela inação deliberadamente funcional do Estado Patrimonialista atuando em contrarrevolução permanente ${ }^{3}$, não suprindo as necessidades de moradia e infraestrutura por meio de políticas públicas inclusivas e que enfrentassem os reais problemas, sobretudo utilizando instrumentos urbanísticos que dialogassem de fato com a precariedade urbana de forma contundente.

Associada a esses processos do capitalismo, a concepção de um ideário de cidade voltada ao transporte individual motorizado foi a tônica do planejamento urbano e diretriz principal dos órgãos de trânsito na cidade de São Paulo como a Companhia de Engenharia de Tráfego $(C E T)^{4}$, que tinha a missão de melhorar a fluidez dos automóveis por meio de políticas e infraestruturas urbanas que priorizavam o automóvel individual e o aumento da sua velocidade $^{5}$. Requena $(2015$, p. 68) apresenta um histórico sobre as políticas de trânsito e o insulamento das burocracias públicas do setor de trânsito e de transporte público na cidade de São Paulo.

A partir de 2013, iniciou-se um processo de inflexão nesse contexto urbano e viário na cidade de São Paulo ${ }^{6}$. Uma primeira abordagem utilizada pela Prefeitura Municipal de São Paulo (PMSP) foi recepcionar as diretrizes do arcabouço jurídico federal introduzido em 2012 pela Política Nacional de Mobilidade Urbana, que priorizava "a integração entre os diferentes modos de transporte e a melhoria da acessibilidade e mobilidade das pessoas e cargas no território do Município" (BRASIL, 2012, p. 01). 0 obstáculo inicial na esfera municipal seria efetivar uma diretriz federal, tendo como desafio superar o estigma dos planos, leis e outros diplomas jurídicos que não se concretizam na prática (MARICATO, 2000, p.152), por falta de regulamentação e implementação em âmbito local.

Nesse contexto, a mobilidade urbana foi discutida intensamente em São Paulo, sendo tema prioritário nos Conselhos Municipais e, posteriormente, consolidado no Plano de Metas (PM) 7 em março de 2013, com uma proposta arrojada e que gerou bastante controvérsia, uma vez que apresentava números audaciosos no sistema de ônibus da cidade, de competência municipal. A meta de número 96 do PM vislumbrava na ocasião a implementação de 150 quilômetros de faixas exclusivas de ônibus. 0 desafio colocado seguido de ceticismo por segmentos sociais vinha, com certa razão, do número reduzido de faixas de ônibus existentes na cidade até o momento, totalizando até 2012 apenas 90 quilômetros ${ }^{8}$. A mudança conceitual trazia para o debate um modelo desigual, desnudando um ordenamento viário que fazia com que os ônibus trafegassem 
Fig. 1: Nova faixa de ônibus na Av. 23 de Maio implementada em 2013. Foto: Renato S. Cerqueira I Futura Press

compartilhando as faixas com os automóveis individuais, mesmo tendo uma capacidade de carregamento muito maior. Esse problema aumentava consideravelmente o tempo de comutação, sobretudo das pessoas que vinham da periferia, em trajetos que duravam 1 a 2 horas. A priorização desigual do espaço entre esses modais também revelava uma disputa de classes, trazendo para a superfície um problema social e político, refletido no desenho de uma política pública de trânsito.

O desempenho dessa política pública em curto período foi bastante revelador. No final de 2016, a cidade teve um aumento de mais de 400 quilômetros de faixas exclusivas de ônibus (Fig. 1), um número impressionante se comparado com a meta inicial de 150 quilômetros e, sobretudo, com o instalado até 2013 de 90 quilômetros, superando a meta estabelecida em 282,2\%. Quais seriam as razões do baixo índice de implementação dessa política de mobilidade urbana, de competência exclusiva do Município, vis-à-vis o que foi implementado nesse curto espaço de tempo? Uma resposta bastante plausível se verifica de duas ordens: uma seria de (falta de) decisão política. Havia dentro dos núcleos de planejamento urbano e viário municipais diversos projetos já desenvolvidos que facilitaram a implementação das faixas exclusivas, aguardando apenas serem "desengavetados". Entretanto, a diminuição do espaço de rodagem dos automóveis individuais geraria um acalorado debate na sociedade e nos meios de comunicação, como de fato ocorreu, fazendo com que as gestões tivessem receio de introduzir uma medida impopular entre as classes abastadas. Um segundo ângulo de análise verifica-se de ordem técnica: além dos trechos de fácil implementação, uma parte deles necessitava de intervenções no viário para acomodar uma faixa exclusiva de ônibus. Pontos de conversões à esquerda, ruas com apenas uma faixa, entre outros "nós" viários necessitavam de pequenas e médias obras, de difícil intervenção pelo caos gerado em decorrência das obras. Isso também geraria um custo político, além de uma necessidade de interlocução com diversos concessionários de serviços públicos, cuja gestão e orquestração das obras era de razoável complexidade.

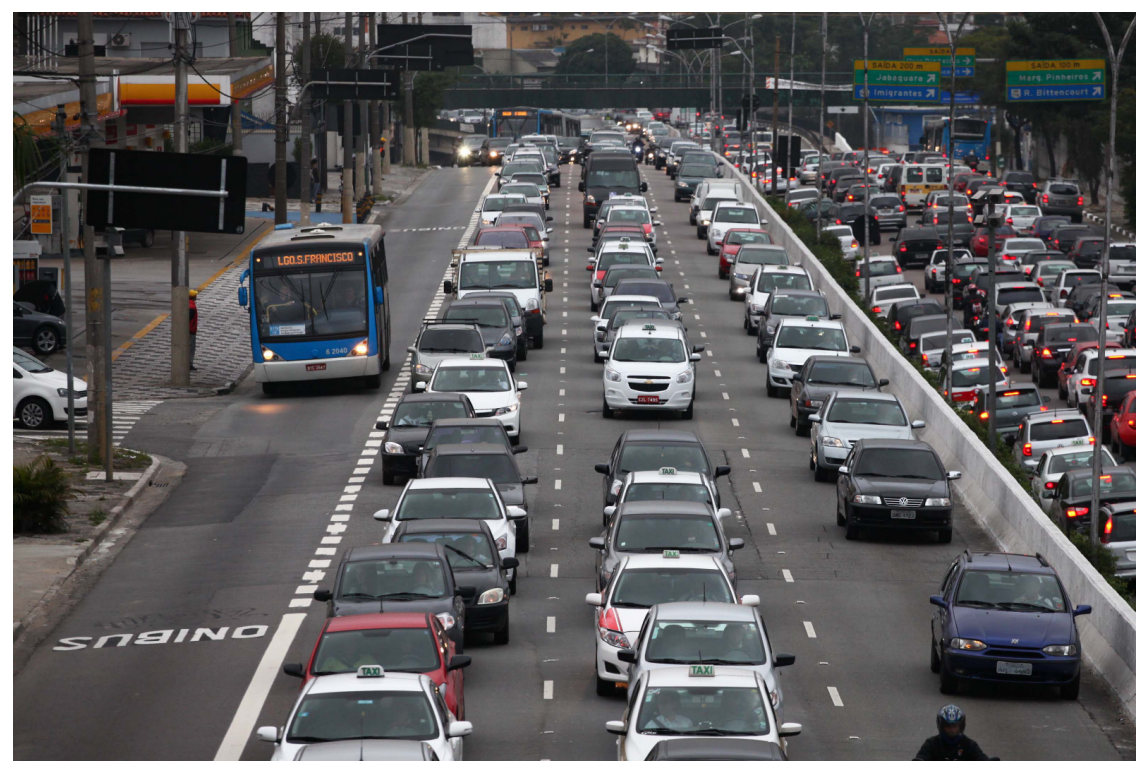

Pós, Rev. Programa Pós-Grad.Arquit. Urban. FAUUSP. São Paulo, v. 25, n. 46, p. 12-31, maio-ago 2018 
A meta 97 do PM pretendia instalar 400 quilômetros de ciclovias e ciclofaixas. Os números se mostravam novamente audaciosos, uma vez que a cidade possuía até aquele momento $96,9 \mathrm{~km}$ de faixas segregadas para bicicletas. 0 objetivo desse programa era ter um planejamento de médio e longo prazo para esse modal, permitindo uma melhor integração com outros modais, ampliar a mobilidade intra e interbairros e, finalmente, aumentar o uso desse transporte na população. Por meio dessa política, pretendia-se desenvolver um enfoque holístico, visando à melhoria dos indicadores de saúde, ambientais e de segurança e evitando acidentes e mortes, pleito constante entre os coletivos e cicloativistas. Novamente, a performance da expansão do sistema cicloviário pretendido foi concluída com êxito, com acalorada repercussão na mídia e disputas envolvendo diversos atores sociais e institucionais, na medida em que cada trecho cicloviário era implementado pela PMSP. Esmiuçaremos esse embate em detalhes mais adiante.

O sistema de ônibus noturno foi outro importante pilar de mobilidade (meta 95) que permitiu uma democratização do acesso para o lazer e para trabalhadores do período noturno, principalmente em uma cidade como São Paulo que apresenta intenso fluxo e vocação para atividades noturnas. Foi implantado um sistema com 151 linhas estruturais e locais, com funcionamento da meia-noite às 4 da manhã, beneficiando por volta de 800 mil usuários por mês, atendendo uma flagrante demanda que era negligenciada até o momento.

De forma não exaustiva, uma série de outras ações foram estruturadas, melhorando a mobilidade urbana e o seu acesso inclusivo. O bilhete único diário, semanal e mensal, assim como diversas gratuidades (passe livre do estudante e diminuição da gratuidade de 65 para 60 anos para idosos) melhoraram o acesso do transporte para segmentos específicos da população. Outras tecnologias foram desenvolvidas como a Zona Azul eletrônica, recarga do Bilhete Único em miniterminais nos ônibus e a regulamentação dos aplicativos de transporte individual ${ }^{9}$.

Algumas políticas pré-acordadas no PM avançaram consideravelmente apesar de não terem atingido sua meta. A acessibilidade dos ônibus foi realizada em pouco mais de $70 \%$ da frota diante de uma meta até 2016 de $100 \%$ dos veículos. Outra meta não atingida foram os $150 \mathrm{~km}$ de corredores de ônibus ${ }^{10}$, perfazendo investimentos da ordem de $\mathrm{R} \$ 2$ bilhões, incluindo os trechos concluídos ou em obras até 2016. Dos $150 \mathrm{~km}$, foram concluídos até 2016 apenas 42,3 km de novos corredores concretados ${ }^{11}$.

Como exame crítico sobre o desempenho da implantação dos corredores centrais, os entraves identificados foram diversos. 0 trecho Leste teve suas licitações preparadas, entretanto alguns procedimentos tiveram seu rito contestado pelos órgãos de controle como o Tribunal de Contas da União (TCM), como de praxe, para esclarecimentos ou ajustes eventuais. Nas parcerias com a União, as fontes de financiamento federais como as do Programa de Aceleração do Crescimento (PAC) diminuíram ou ficaram pendentes de liberação diante do ajuste fiscal e da queda de arrecadação do Governo Federal. Por fim, as 5000 desapropriações previstas inicialmente para implantação de todos os corredores, terminais e seus acessos, caracterizaramse como um importante entrave no desempenho desta política, tanto em 
âmbito burocrático, quanto devido aos elevados recursos necessários para efetivar essas desapropriações no Judiciário. Assim, é plausível afirmar que os previsíveis entraves de desapropriação e a aposta exclusiva nos recursos federais para determinados projetos não foram, em certa medida, corretamente dimensionados, se mostrando estrategicamente frágil na sua concepção.

Cabe destacar que o cumprimento das metas do PM era medido de forma distinta entre as instituições, cada uma utilizando um modelo de acordo com sua conveniência analítica. Com essa falta de consenso metodológico, havia uma discordância no cumprimento ou não de algumas metas ${ }^{12}$. Como exemplo, diversos trechos encontravam-se com suas licitações e licenciamentos bastante encaminhados ${ }^{13}$, no entanto, esses estágios não eram computados nas aferições de certas instituições ou parte da mídia.

Outro importante capítulo na quebra do paradigma rodoviarista em São Paulo foi a ativação dos espaços públicos a partir de 2013. A colocação do pedestre, do transporte público e das bicicletas como protagonistas - em detrimento do automóvel - foi um ponto de inflexão fundamental no desenvolvimento das políticas públicas urbanas. Na prática, as revisões da normativa urbanística, previstas em lei e iniciadas em 2013 com o Plano Diretor Estratégico (PDE) ${ }^{14}$, continham esses conceitos basilares, disseminados de forma gradual entre os técnicos e colocados em pauta nas inúmeras deliberações públicas. Além disso, a orientação do adensamento estratégico em áreas com transporte público, utilização de fachada ativa nos prédios, uso misto e de renda e a flexibilização no nível mínimo de garagem para automóveis nos prédios foram contribuindo gradativamente para que houvesse uma mudança de ideário na produção do urbano em São Paulo, propiciando a ativação das áreas públicas da cidade para o lazer, esporte e cultura.

Como exemplos desse processo temos programas que modificaram o uso do espaço público em São Paulo: o programa Ruas Abertas/Paulista Aberta e o Carnaval de Rua personificam essa mudança conceitual na ocupação da cidade. O Ruas Abertas tinha o objetivo de ser implementado em todas as 32 Subprefeituras, tendo o conceito de abrir o viário para o uso de pedestres aos domingos. O simbolismo de se fechar a principal avenida do país para o fluxo de automóveis gerou enorme debate público, de grupos antagônicos. Já o Carnaval de Rua teve crescimento notável a partir de 2013, com a Secretaria de Cultura estimulando e recepcionando a adesão de "blocos de ruas nos bairros" por toda a cidade. Com o ajuste de falhas que ocorriam durante a operação devido ao enorme crescimento de foliões, por meio da melhoria da infraestrutura (aumento de banheiros químicos, melhoria das regras de convivência e horários, policiamento, entre outros), o Carnaval de São Paulo se consolidou, aumentando de, aproximadamente, 100 blocos em 2013 para quase 500 em 2016, chegando a ser o segundo maior Carnaval de rua do país. Todas essas ações não foram implementadas sem um duro embate social, técnico e político, envolvendo diversos atores em inúmeras rodadas de negociação ao longo de todo o período.

Diversas intervenções urbanas realizadas de forma "cirúrgica", modificaram o uso do espaço público, ativando locais que geravam inclusive a sensação de insegurança. O programa Centro Aberto e a utilização de minipraças no leito 

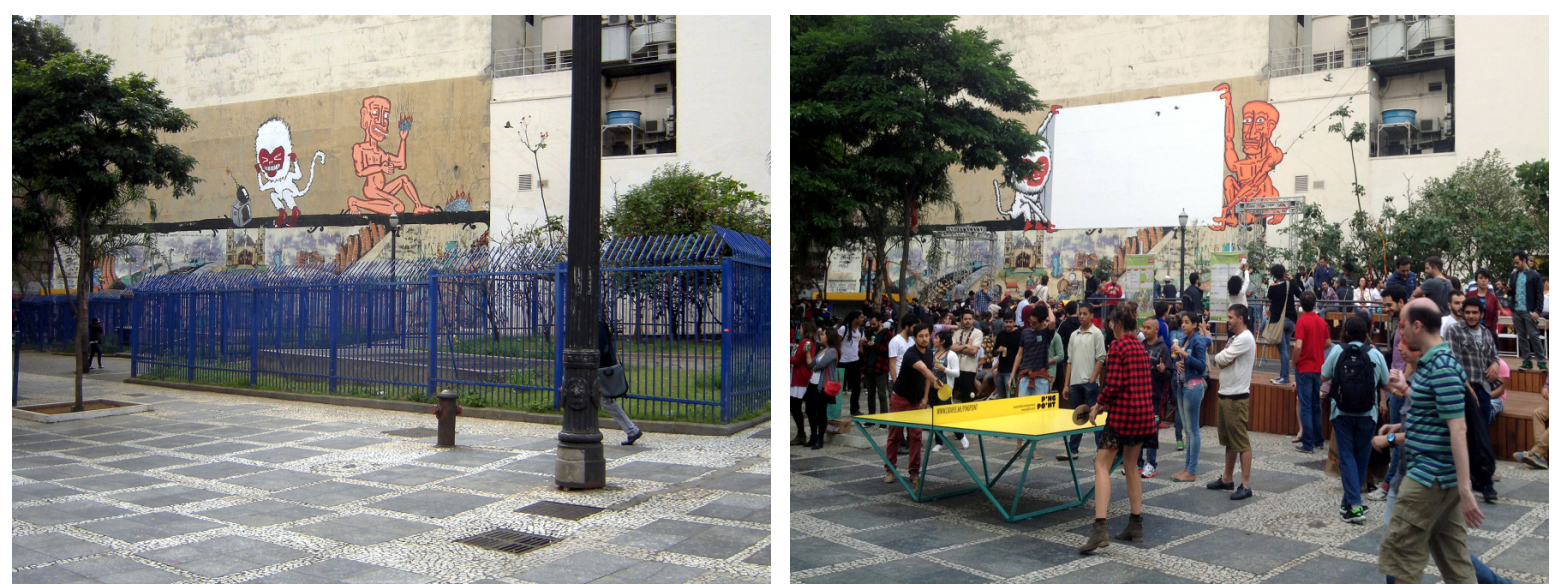

Fig. 2. Programa Centro Aberto I Largo São Francisco, São Paulo: antes e depois, 2015 I Foto: Eduardo Pompeo
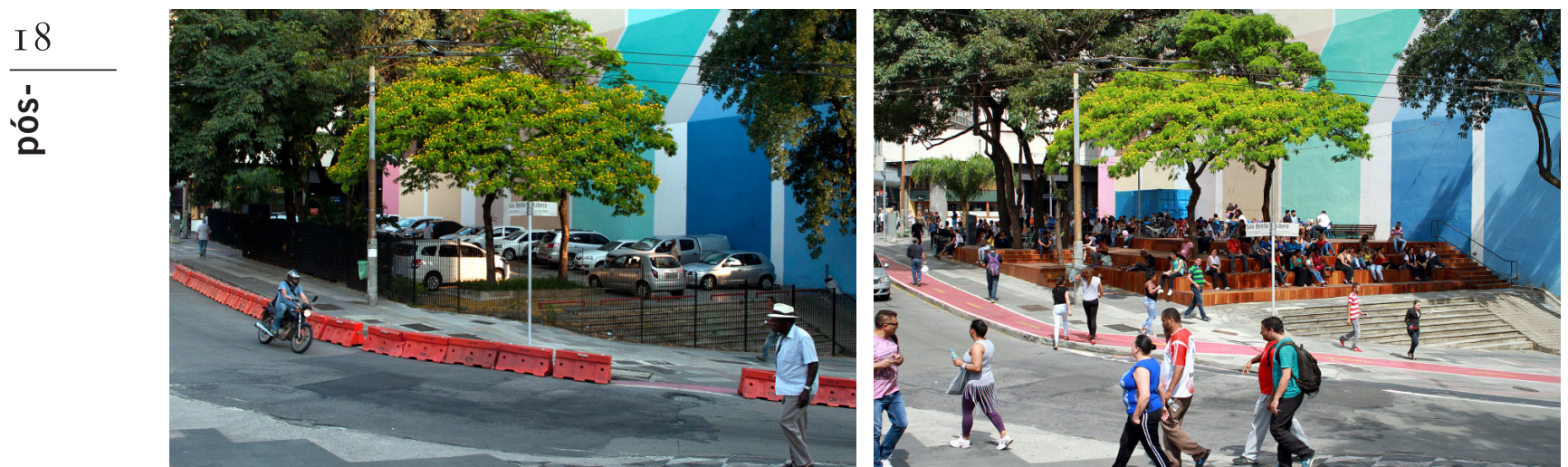

Fig. 3. Programa Centro Aberto I Largo São Bento, São Paulo: antes e depois, 2014 I Foto: Eduardo Pompeo

carroçável proporcionou o uso de locais estratégicos como o Largo São Francisco (Fig. 2) e Praça São Bento (Fig. 3) no centro da cidade.

A restauração de importantes âncoras culturais foi outro alicerce catalisador da cidade que trouxe enorme dinamismo e fluxo cultural para a cidade. 0 desafio, nesse caso específico, consistia em enfrentar os entraves burocráticos para a complexa reforma e respectivas licitações desses equipamentos, que possuíam sofisticados maquinários, necessitando complexa coordenação intersecretarial na PMSP (como exemplo, temos os Planetários do Ibirapuera e do Carmo que estavam inativos desde 2009 e 2004, respectivamente). Outros equipamentos como o Teatro Flávio Império, Teatro Paulo Eiró, Casas de Cultura, Salas de Cinema da SP Cine e Clube do Choro foram (re)inaugurados proporcionando enorme dinamismo cultural na cidade.

Uma outra mudança importante no trato do interesse social foi o resgate de ativos públicos, que foram apropriados e privatizados em gestões anteriores da PMSP, reabrindo-os para o uso da população de forma não onerosa. Foi o caso 
do Clube Tietê: o terreno municipal tinha sido cedido para uso exclusivo e privado. Com a recuperação da área pela municipalidade, ele foi transformado em parque público, ativando um espaço importante para a população da região central e norte da cidade. 0 mesmo ocorreu com o Parque do Jockey, de propriedade do Jockey Clube de São Paulo: em troca da enorme dívida do Jockey com a Prefeitura, que se arrastava por décadas, houve o resgate do clube, que era privado, sendo aberto pela Prefeitura para a comunidade após ampla readequação do espaço. Esse novo olhar inclusivo, de recuperação e abertura de áreas privadas para o uso público, foi a tônica usada no período em diversos locais da cidade $^{15}$.

Como perspectiva histórica, é importante ressaltar que gestões municipais anteriores ao quadriênio analisado também realizaram avanços na ocupação do espaço público e na melhoria da mobilidade urbana. Vários autores analisaram as diferenças entre governos com relação às suas abordagens na alocação dos investimentos públicos, evidenciando uma maior orientação rodoviarista ou com foco no transporte público de massa. Verificamos em Rolnik e Klintowitz (2011, p. 103) a variação desses investimentos entre as diferentes gestões, constatando que, após alguns anos de investimentos significativos em transporte coletivo na primeira metade dos anos 2000, a segunda metade da década presenciou "uma retomada do investimento em sistema viário e na reafirmação do modelo histórico de anéis perimetrais e de 'rodovias urbanas', com a implantação de projetos como o Rodoanel, a ampliação da Marginal do Rio Tietê e um pacote de obras viárias". Marques (2003) examina o padrão de investimentos públicos na Secretaria de Vias Públicas (SVP) da PMSP16, investigando também suas complexas redes, esmiuçando a relação entre a burocracia pública e os agentes privados nos governos de esquerda e de direita nas gestões municipais em São Paulo. Assim, na área da mobilidade urbana, os investimentos em corredores de ônibus ${ }^{17}$, de atribuição (quase que) exclusiva do Município, marcaram o início de um confronto com a matriz rodoviarista na cidade de São Paulo. Ademais, de forma não exaustiva, diversas leis, políticas públicas e investimentos no tecido urbano ajudaram a melhorar, ainda que de forma insuficiente, a relação da cidade com o pedestre: os CEUs nas periferias, intervenções urbanas específicas - como a reforma da Praça Roosevelt na região central -, a implantação de ciclofaixas temporárias aos domingos e feriados e, sobretudo, a revisão do PDE de $2004^{18}$.

Diante do que foi exposto anteriormente nessa seção, acreditamos que, entre 2013 e 2016, as políticas públicas urbanas implementadas no período tiveram uma escala e velocidade de implementação maior, comparativamente às outras gestões municipais, produzindo uma mudança positiva na relação do pedestre com a cidade, tornando-a mais inclusiva e democrática. 0 crescente processo de ativação dos espaços públicos e, sobretudo, de confronto permanente com a matriz rodoviarista da cidade, em curto espaço de tempo, personificava um ideário urbano defendido pela gestão. A concretização das ações que representavam essa visão de cidade se deu, não somente pelas diretrizes de governo e pelas políticas públicas implementadas, mas, também, por um respaldo político importante, que municiou a Prefeitura para um enfrentamento sólido na articulação com diversos estratos sociais conservadores da cidade - defensores do modelo rodoviarista e privatista - que será abordado adiante. 


\section{Alocação dos investimentos públicos: CENTRO EXPANDIDO VERSUS PERIFERIA}

A conformação das cidades no Brasil foi moldada ao longo do tempo por um mecanismo perverso de alocação dos recursos públicos de infraestrutura. 0 processo decisório para sua destinação ocorreu sem um processo deliberativo e de participação social inclusiva e transparente, havendo, invariavelmente, uma captura pelos agentes privados e do mercado imobiliário. Assim, esses grupos se beneficiaram desses investimentos públicos, ora para valorizar ainda mais seus ativos já instalados, ora para criar novas frentes imobiliárias - como o setor sudoeste em São Paulo -, concentrados, portanto, nas áreas ocupadas pelos setores de alta renda, conforme foi analisado por diversos autores ${ }^{19}$. Diante desse planejamento urbano casuístico, a cidade de São Paulo tornouse desordenada em termos de mobilidade, intensificando ainda mais a segregação socioespacial, uma vez que regiões populosas da cidade carecem cada vez mais de investimentos de infraestrutura. Nesse contexto, milhares de pessoas têm que se deslocar entre 3 e 5 horas diariamente, devido à mobilidade urbana sobrecarregada nas periferias, além do déficit em outras áreas como emprego, moradia, saneamento e saúde, exacerbando a condição de exclusão e baixa qualidade de vida dessas famílias que moram nas franjas das cidades brasileiras. Em resumo, a alocação dos investimentos do Estado (patrimonialista) deveria ter proporcionado maior justiça social, mitigando a segregação socioespacial e promovendo o acesso à terra urbanizada para as famílias. De forma perversa, agiu ao contrário: desde o início, o que prevaleceu foram investimentos estatais implementados nas áreas de melhor localização da cidade, já com infraestrutura e serviços e onde se encontrava a população de mais alta renda. Dessa forma, ao contrário de combater a desigualdade social e espacial, o Estado tem contribuído para a valorização da terra urbana, favorecendo assim os segmentos abastados e o mercado imobiliário. Diante do quadro de exclusão e desigualdade socioespacial na cidade de São Paulo, o direcionamento de maiores investimentos para as

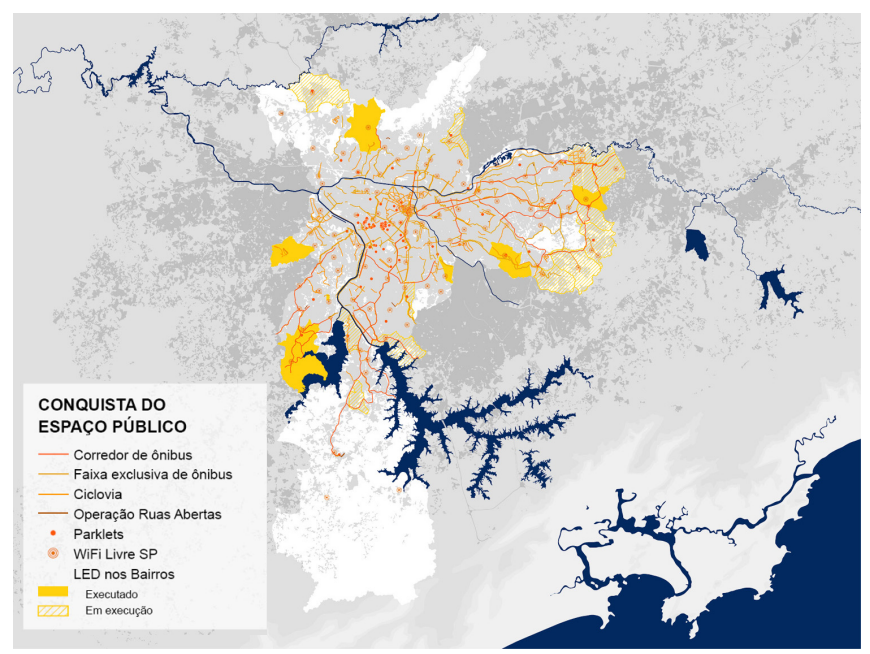
áreas periféricas da cidade deveria ser a tônica da municipalidade. Entretanto, diversos estudos apontam que isso ocorre de forma inversa, devido a um processo de captura do Estado pelas elites e pelo capital, em linha com o marxismo urbano dos anos 1970 no Brasil (MARICATO, 1996; BONDUKI, ROLNIK, 1982).

Conforme estudo empírico dos investimentos públicos implementados nesse recorte temporal, realizamos o georreferenciamento das obras em infraestrutura e equipamentos públicos, retratados nos mapas a seguir:

Mapa 01: Conquista do Espaço Público

Fonte: PMSP, 2016 

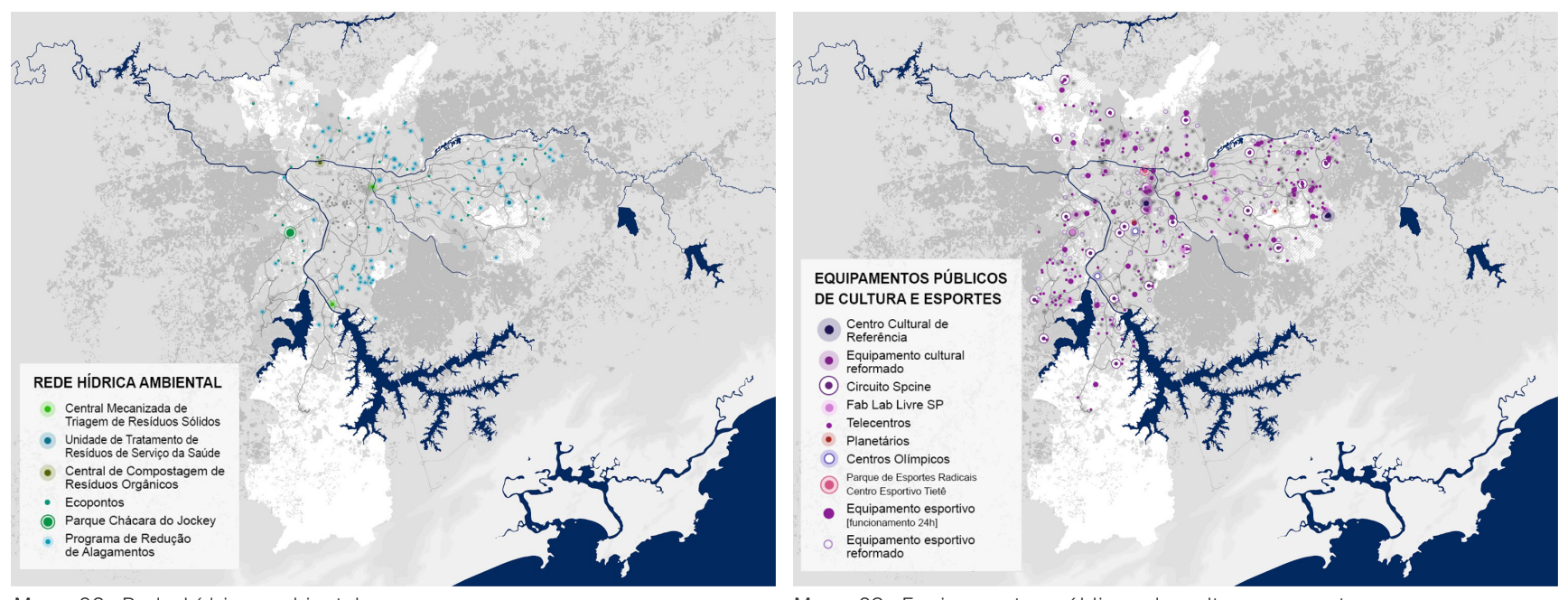

Mapa 02: Rede hídrica ambienta Fonte: PMSP, 2016

Mapa 03: Equipamentos públicos de cultura e esportes Fonte: PMSP, 2016

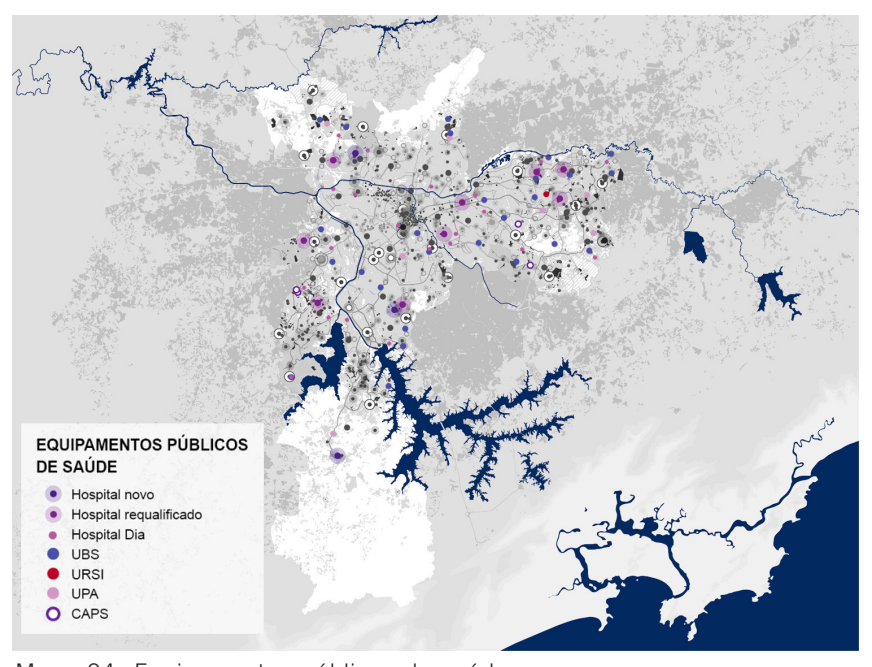

Mapa 04: Equipamentos públicos de saúde Fonte: PMSP, 2016

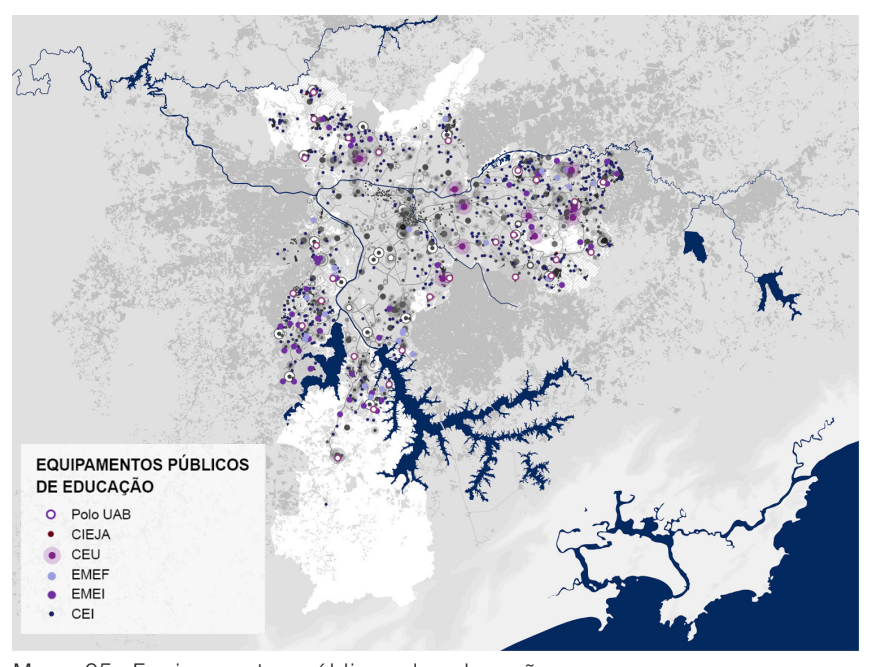

Mapa 05: Equipamentos públicos de educação

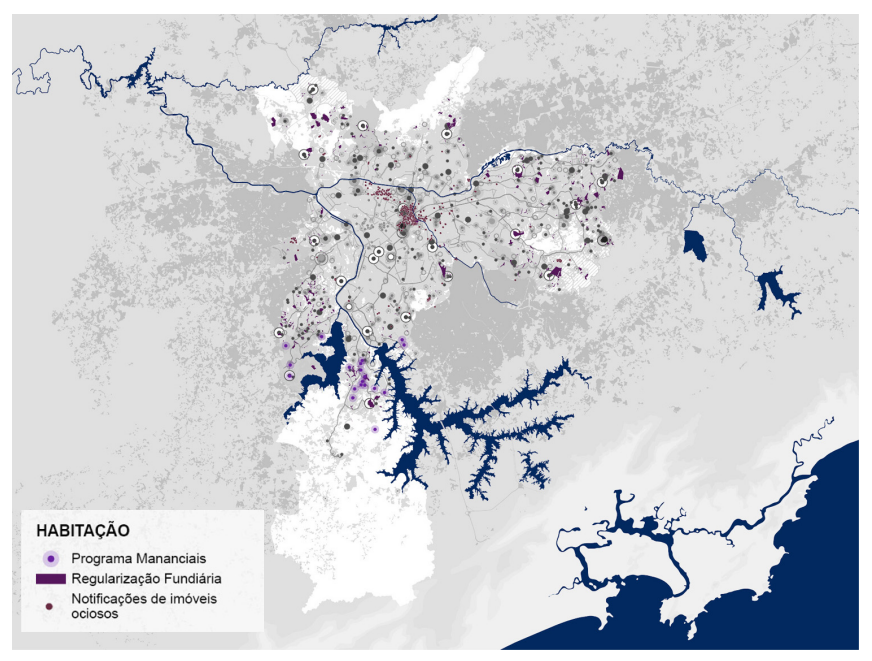

Mapa 06: Habitação

Fonte: PMSP, 2016

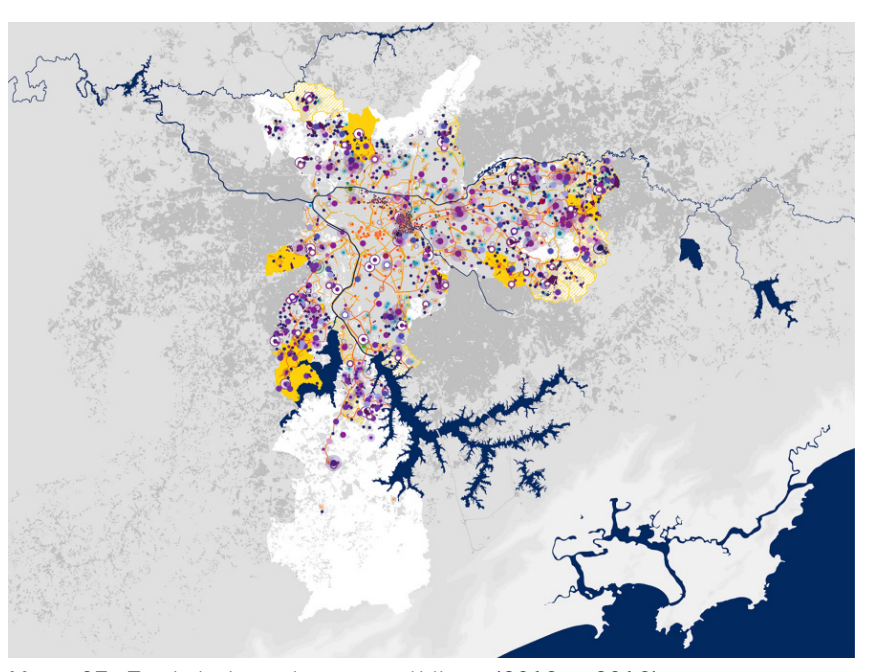

Mapa 07: Total de investimentos públicos (2013 - 2016)

Fonte: PMSP, 2016 
Indo na contracorrente histórica de investimentos públicos na cidade de São Paulo20, a análise feita no quadriênio 2013 e 2016 mostra uma clara concentração dos investimentos públicos fora do centro expandido ${ }^{21}$ da cidade de São Paulo, que é a região que concentra a população de maior vulnerabilidade social e com maior demanda em infraestrutura urbana, além de possuir quase que a totalidade de áreas que necessitam de regularização fundiária, excluídas da cidade formal e de mercado (MARICATO, 2000). Essa situação se agrava bastante na medida em que avançamos para os distritos que fazem divisa com outros Municípios da Região Metropolitana de São Paulo (RMSP), sobretudo nas áreas de mananciais que apresentam alta vulnerabilidade ambiental.

No Mapa 01 foram agregados diversos investimentos públicos que faziam parte conceitualmente da conquista do espaço público. Apoiado em um ideário urbanístico contemporâneo, esses recursos - majoritariamente realizados em áreas da periferia - ativariam a cidade, democratizando o uso do espaço público. No mapa, apresentamos a geolocalização de corredores e faixas de ônibus, praças wifi livre, minipraças (parklets) e sistema cicloviário.

A instalação das luminárias de LED merece uma menção específica pelo seu caráter dinamizador nas franjas da cidade. Com a melhoria da iluminação de LED em pontos, ora sem iluminação como vielas e escadarias, ora com iluminação insuficiente, proporcionou uma mudança substancial na dinâmica desses bairros. Áreas como Monte Azul, Guaianases, Cidade Tiradentes, Pedreira, Heliópolis, entre outros ${ }^{22}$ receberam prioritariamente 86.926 lâmpadas de LED com capacidade de iluminação muito maior que a convencional, beneficiando cerca de 2 milhões de pessoas. Vale, portanto, ressaltar o foco dos investimentos nos bairros periféricos, com alto índice de violência e vulnerabilidade social vis-à-vis os bairros centrais que já possuem boa capacidade de iluminação ${ }^{23}$.

Os investimentos em infraestrutura urbana para a contenção de cheias em algumas bacias hidrográficas da cidade foram realizadas em locais estratégicos da periferia como nos Córregos Aricanduva, do Cordeiro, Morro do S, Paciência, Ponte Baixa, Tremembé, Paraguai/Éguas, Zavuvus, Riacho do Ipiranga, e Ribeirão Perus. Com exceção das obras realizadas no Córrego Sumaré/Água Preta, na região central da Lapa, todas as outras obras foram localizadas em bairros periféricos. Além dessas outras de grande magnitude, o Programa de Redução de Alagamentos (PRA) realizou mais de 70 intervenções de pequeno e médio porte em córregos da periferia e pontos de alagamento no viário ${ }^{24}$.

No mapa 04, apontamos os principais equipamentos de saúde implementados no intervalo analisado por esse ensaio - três Hospitais Gerais - na Vila Santa Catarina, Brasilândia (em obras) e em Parelheiros (em obras) - assim, como os Hospitais Dia/Rede Hora Certa ${ }^{25}$ com 30 unidades (8 ainda em obras em 2016), que também foram majoritariamente investidos em áreas bastante vulneráveis na cidade. No mapa 05 , os maiores investimentos públicos em educação - CEUs e creches - seguiram a mesma regra de priorização dos investimentos: alocados substancialmente em áreas periféricas de São Paulo. Verificamos, portanto, que saúde e educação, consideradas áreas prioritárias em qualquer gestão, tiveram investimentos estruturais importantes realizados no período. 
O caso da habitação, representado no mapa 06, apresenta lógica inversa das outras áreas como saúde, cultura, educação e infraestrutura: idealmente, o investimento em habitação teria mais impacto social na medida em que fosse alocado dentro do centro expandido e próximo da rede de transporte público. Entretanto, as forças especulativas do mercado imobiliário, com seus vetores de gentrificação, promovem a apreciação da terra urbanizada e infraestruturada da região central, expulsando os moradores de menor renda, fazendo com que a maioria das famílias não consiga acessar o mercado formal imobiliário. Nesse contexto, a estratégia adotada foi atuar em duas frentes: aderir ao programa Minha Casa, Minha Vida (PMCMV); segundo, efetuar um programa de regularização fundiária. Em linhas gerais, a adesão ao PMCMV não permitiu a viabilização de muitas unidades nas áreas centrais próximas dos empregos e evitando grandes movimentos pendulares diários. O alto custo da terra inviabilizava a inserção de moradias nesses locais, fazendo com que os empreendimentos fossem incorporados em áreas periféricas, indo na contramão do manual urbanístico.

Apesar do desempenho consistente na viabilização de parcela importante da meta 35 de 55 mil moradias, esta não foi atingida. De forma crítica, a adesão da cidade ao PMCMV como "aposta" (quase que) exclusiva como política habitacional se mostrou frágil. Com a demora nos repasses federais e, recentemente, com o corte considerável no programa em 2017, diversos empreendimentos municipais ficaram parados ou tendo que reformular o modelo de negócios para sua incorporação. Por outro lado, a estratégia de aquisição de diversos terrenos pela PMSP se mostrou correta, pleito esse recorrente dos movimentos de moradia. Em linhas gerais, a aposta irrestrita no PMCMV mostrou-se insuficiente, uma vez que houve abrupta diminuição de recursos federais decorrentes do ajuste fiscal diante da crise econômica.

A regularização fundiária foi outra importante frente de ação, promovendo um enorme impacto na cidade informal: loteamentos irregulares e assentamentos foram gradualmente cadastrados e georreferenciados, empoderando diversas comunidades com o título de propriedade do imóvel com a certidão registrada nos cartórios ${ }^{26}$.

Uma crítica importante da política habitacional no período se revela de duas ordens: a regularização fundiária poderia ter sido combinada com ações de urbanização dos assentamentos precários, com investimentos mais robustos partindo de projetos específicos de urbanização e infraestrutura. Uma segunda crítica da pasta foi o foco tardio no desenvolvimento do Plano Municipal de Habitação $(\mathrm{PMH})^{27}$, que foi elaborado no último ano da gestão, em 2016. Com isso, importantes programas como a locação social - que poderia ter estruturado habitações de interesse social no centro de São Paulo ${ }^{28}$ - não puderam ser viabilizados em tempo hábil.

Em suma, não pretendemos nesse ensaio apresentar um quadro exaustivo dos investimentos públicos realizados no ciclo analisado ${ }^{29}$. Por meio dos mapas esquemáticos apresentados e de estudo empírico que analisou o total de investimentos realizados pela PMSP nesta gestão, utilizando ferramentas de georreferenciamento, pudemos comprovar a hipótese inicial: que os investimentos públicos realizados no quadriênio 2013 - 2016 foram majoritariamente realizados nas regiões além do centro expandido da capital 
paulista. De forma específica, dos investimentos no período que perfizeram pouco mais de $\mathrm{R} \$ 15$ bilhões, por volta de $70 \%$ desse valor foi invertido em áreas de alta vulnerabilidade na cidade de São Paulo ${ }^{30}$.

\section{A SOCIEDADE PATRIMONIALISTA E A COMPLEXA REDE SOCIAL E INSTITUCIONAL DA CIDADE DE S ÃO PAULO}

A implementação de políticas públicas que enfrentaram o paradigma rodoviarista e a estrutura social elitista em São Paulo, conflagrou a mobilização de uma miríade de atores sociais e institucionais, seja para conservar esse cenário (ainda) vigente de iniquidade e segregação socioespacial, seja em prol de mudanças desse ideário enraizado na cidade.

Assim, São Paulo se tornou um imenso campo de batalha, com cada intervenção urbana sendo disputada palmo a palmo. Ao mesmo tempo que eram saudadas por alguns segmentos, as mudanças urbanísticas conduzidas pela PMSP foram questionadas por diversas entidades como segmentos da mídia, Ministério Público Estadual (MPE), Tribunal de Contas do Município (TCM) e a Câmara Municipal de São Paulo (CMSP), além de estratos sociais de diversos matizes, para citar alguns.

Uma hipótese que retrataria os embates do período estudado poderia ser resumida da seguinte forma: que a cidade de São Paulo possui uma elite que não tem real interesse em propor, e tampouco apoiar, políticas que promovam mudanças estruturais para mitigar a segregação socioespacial, tendo forjado esse cenário ao longo do tempo por meio da imiscuição com um Estado Patrimonialista capturado, em linha com a análise de Faoro (1976), apoiandose mutuamente a perpetuar essa condição de desigualdade. Não temos o objetivo de explorar em detalhes esse ângulo de análise nesse ensaio. Entretanto, acreditamos haver evidências entre 2013 e 2016, que revelaram a faceta patrimonialista ${ }^{31}$ da sociedade, tendo atuado de forma proeminente para preservar esse quadro social excludente.

Entendemos que diversas políticas públicas do período analisado enfrentaram os reais problemas promotores da segregação socioespacial da cidade, ainda que a forma e o compasso acelerado de implementação de algumas medidas possam ser passíveis de críticas e ajustes ${ }^{32}$. Dessa forma, uma possível evidência - suscetível de maior aprofundamento - para comprovação da hipótese da atuação perversa do Estado e sociedade patrimonialistas, foi simbolizada pela atuação de atores sociais e institucionais, combatendo essas políticas de forma incisiva e articulada de suas trincheiras, uma vez que elas ameaçavam pilares importantes desse status quo. Como abordagem analítica, o Modelo das Coalizões de Defesa (MCD) de Paul Sabatier ${ }^{33}$ seria um ferramental metodológico adequado para identificar a atuação dessas coalizões, qualificando seu respectivo alinhamento social, político e econômico ou suas motivações ad hoc, enquadrando esses grupos (antagônicos) em um subsistema, que defendiam seus respectivos interesses e usavam seus recursos para bloquear ou destravar a implementação de determinada política do governo. 
Nesse contexto, a PMSP por vezes era o foco central de contestação de grupos específicos contrários às suas intervenções. Em outras situações, era a mediadora de grupos antagônicos. Um dos casos que mais ilustram esse embate foi a atuação dos meios de comunicação em todo o período. Conforme versão exposta pelo Prefeito Fernando Haddad posteriormente, o segmento se trata de um "oligopólio econômico que funciona como monopólio político ideológico" (HADDAD, 2017, p. 31). Uma análise pormenorizada, com levantamento empírico sobre os editoriais e matérias realizadas pelos principais jornais e canais de televisão seria de grande valia para entender, não só eventual (im-)parcialidade na produção e análise jornalística das políticas públicas implementadas no período, como também revelar efeitos da crise econômica e estrutural que passam esses conglomerados, influenciando na sua atuação. Questões como: quem financiou cada veículo ao longo dos anos e em qual medida? Existe, de fato, um oligopólio e, se sim, como ele atua? Qual a independência desses grupos para criticar eventuais patrocinadores? Em suma, a contribuição de um estudo empírico seria fundamental, tendo o objetivo de identificar (ou não) eventuais conflitos de interesse e parcialidade jornalística na análise de mérito sobre as políticas implementadas dada a atipicidade desse período.

A revisão da Planta Genérica de Valores (PGV) do Imposto Predial e Territorial Urbano (IPTU) foi outro capítulo atípico na cidade, uma vez que todas as gestões anteriores não tiveram problemas em atualizar os valores do IPTU. Neste caso, o embate se deu entre a Federação das Indústrias do Estado de São Paulo (FIESP), representada pelo seu presidente Paulo Skaf, e o Partido da Social Democracia Brasileira (PSDB) contra a $\mathrm{PMSP}^{34}$ e mediado pelo Judiciário. Com uma liminar, a FIESP conseguiu barrar a atualização do IPTU, sendo apreciada pelo Supremo Tribunal Federal (STF), cujo pedido da PMSP pela cassação da liminar foi negado. Apenas um ano depois, outra instância do Judiciário, o Tribunal de Justiça de São Paulo, reverteu esse impedimento. A pergunta que cabe ser feita é: porque o STF manteve a liminar? Quais áreas em São Paulo tiveram aumento e quais tiveram isenções vis-à-vis a valorização desses imóveis na proposta de atualização do IPTU apresentada pela PMSP? Como reparar para a cidade a perda de arrecadação de mais de $\mathrm{R} \$ 700$ milhões em 2014 por conta dessa liminar? Uma melhor análise dessas e de outras questões sobre o IPTU e a estrutura fundiária em São Paulo também mereceria uma investigação mais aprofundada.

Atores institucionais importantes do sistema político e institucional - como o MPE, TCM e CMSP - também atuaram intensamente. Suas ações, muitas vezes conjugadas com a sociedade civil organizada, geraram disputas cotidianas no período, em litígios com várias rodadas de negociação. 0 ex-Prefeito de São Paulo ofereceu novamente sua interpretação: "as instituições que deveriam apenas 'garantir o jogo' democrático têm apetite por 'jogar o jogo', o que o torna menos democrático" (HADDAD, 2017, p. 32). Entre outras informações, fez acusação nominal ao Procurador Marcelo Milani, do MPE, sobre sua atuação em alguns casos específicos, levantando suspeição sobre sua conduta ética. Outro caso marcante foi a atuação do MPE no processo de implementação de duas políticas públicas na Avenida Paulista: a Paulista Aberta e as obras da ciclovia no local. No primeiro caso, o MPE teve atuação contundente quando a PMSP implementou a abertura da via para pedestres 
aos domingos, após longo processo de audiências e consultas públicas e interlocução com a sociedade civil organizada e hospitais da região, multando a Prefeitura em R\$50 mil ${ }^{35}$. 0 embate entre o MPE e a PMSP se deu por conta de um Termo de Ajustamento de Conduta (TAC) assinado em $2007^{36}$. No caso da ciclovia, a promotora Camila Mansour Magalhães entrou no Judiciário com uma ação, pedindo que as construções das ciclovias em toda a cidade fossem suspensas, em um prazo de 24 horas, dizendo que "a decisão política de desenvolvimento do sistema cicloviário neste município, adotada pela atual gestão municipal, viola o princípio constitucional da eficiência" e "não atende ao interesse público" (MARTíN, 2015, p. 02).

O TCM, órgão de controle do Executivo, com força institucional de bloquear suas ações como licitações, além de ter a competência de validar suas contas diferentemente do MPE que pode unicamente promover ações contra a PMSP via Judiciário - historicamente é um centro de barganhas políticas, com os principais cargos preenchidos por indicações do Legislativo e da PMSP (um dos cinco conselheiros é, habitualmente, indicação da municipalidade). Ou seja, sua atuação, que deveria ser puramente técnica, possui uma orientação consideravelmente política, dada a filiação e indicação de partidos políticos aos cargos, inclusive dos Conselheiros, que ditam a dinâmica e as pautas de análise do órgão. Como ilustração, a CMSP instaurou uma Comissão Parlamentar de Inquérito (CPI) do TCM em 2001, apresentando um relatório sobre a conduta institucional desta corte, levantando indícios sobre nepotismo, atuação política e problemas de licitação ${ }^{37}$ (CMSP, 2001). Novamente, houve um problema institucional entre a PMSP e um conselheiro específico dentre os cinco conselheiros conforme noticiado na época (DIÓGENES, 2015). Uma análise específica sobre a atuação do órgão, examinando seu desempenho institucional, assim como os prazos e ritos seguidos por cada Conselheiro, traria maior clareza sobre as condutas burocráticas dos mesmos e, sobretudo, se influências políticas e ideológicas atuariam neste órgão de controle, que deveria ser eminentemente técnico.

Por fim, a sociedade civil organizada mostrou intensa mobilização neste quadriênio. Com as mudanças em ritmo acelerado em diversas áreas, as políticas públicas entraram no debate cotidiano da população. Isso foi um aspecto bastante relevante, propiciando maior dinamismo e engajamento social de diversos grupos sociais, ampliando o nível de deliberação democrática. Desde as inúmeras consultas e audiências públicas nas revisões do marco regulatório urbanístico como o Plano Diretor Estratégico (PDE) e o Zoneamento, até as implantações das ciclovias e discussões do Plano de Mobilidade (PlanMob) (SÃO PAULO, 2016), passando pelo acalorado debate da Paulista Aberta e do confronto dos aplicativos de mobilidade individual versus taxistas, a cidade teve um período efervescente de mobilização, ora apoiando as medidas, ora sendo radicalmente contra, num contexto de quase polarização e antagonismo.

Em suma, o período examinado se mostrou bastante atípico pelo conteúdo progressista de suas políticas públicas e pela intensa repercussão e enfrentamento social. Assim, esse recorte temporal se mostra potencialmente valioso, suscitando uma maior investigação. O escopo deste estudo se ocuparia, primeiramente, dos efeitos gerados pela intensa revisão normativo-jurídica, 
associada às políticas públicas implementadas, medindo seu real impacto na atenuação da desigualdade social. Em outro plano, conduziria a um levantamento empírico sobre a atuação - orquestrada ou espontânea - dos atores institucionais e sociais supramencionados, investigando as coalizões atuantes no período, esmiuçando suas motivações, crenças e demandas. Entendemos que essas análises mais aprofundadas são imperiosas, devendo estar na ordem do dia.

\section{Notas}

${ }^{1}$ Ver uma análise da cidade informal em Ferreira (2007, p. 23).

2 Conceito em linha com a crítica marxista sobre os problemas da questão urbana desenvolvida por diversos autores como Lefebvre, Harvey, Castells, Lojkine, Topalov e Maricato, para citar alguns.

3 Termo cunhado por Fernandes (2007, p. 86), que seria definido por estratégias e manobras políticas, econômicas e sociais utilizadas pelas elites (e seus meios de produção e de comunicação) para a manutenção da ordem e do status quo vigente, sobretudo quando a subversão dos grupos dominados ou a revolta das elites dissidentes adquirem força suficiente para contestar estruturalmente sua posição de dominação.

4 O histórico de políticas viárias e de trânsito estão bastante atreladas ao engenheiro Roberto Scaringella que atuou em diversos departamentos de trânsito e transporte desde 1968. Foi fundador e presidente da CET de 1976 a 1982 e de 2005 a 2008, sendo também presidente do Conselho Nacional de Trânsito.

5 Um dos órgãos internacionais de trânsito que exercia influência nas políticas das cidades brasileiras foi o Transportation Research Board (TRB) por meio da sua publicação Highway Capacity Manual (HCM).

${ }^{6}$ De forma gradativa, houve uma mudança importante na matriz conceitual de órgãos específicos dentro da PMSP. Núcleos como a CET, SP Trans e SP Urbanismo foram estimulados a utilizar diretrizes urbanísticas e de trânsito com foco no pedestre (e não no aumento da velocidade dos carros), além de promover a ativação de espaços públicos tornando-os convidativos para o uso cotidiano da população, associado a melhoria do mobiliário urbano e calçadas, da introdução de políticas de redução da velocidade para a diminuição de acidentes e do desenvolvimento de infraestrutura cicloviária, como preconizava a Política Nacional de Mobilidade Urbana de 2012.

7 O Plano de Metas 2013-2016 apresentava uma série de programas e políticas públicas em diversas áreas. Ateremo-nos neste ensaio às ações de mobilidade e espaço urbano (SÃO PAULO, 2013).

8 Ressaltamos aqui a diferença entre faixa exclusiva, localizada do lado direito da via, e corredor de ônibus, localizada no lado esquerdo da via, com pontos de parada no canteiro central do viário. Em 2013, os corredores de ônibus perfaziam 120 quilômetros (como as avenidas 9 de julho, Rebouças, Santo Amaro, entre outras).

${ }^{9}$ A regulamentação dos aplicativos de transporte individual foi conduzida pela PMSP, sendo uma das primeiras cidades do mundo a autorizar a ação desses aplicativos, introduzindo uma regulação que cobrava dessas empresas pelo uso do viário público por km rodado, possibilitando a inversão de recursos para os cofres públicos e também dando mecanismos de regulação para a PMSP equilibrar a oferta e demanda entre a frota desses aplicativos e os táxis comuns.

${ }^{10}$ A meta 93 determinava que a Municipalidade deveria "projetar, licitar, licenciar, garantir a fonte de financiamento e construir 150 km de novos corredores de ônibus”, ou seja, deixar a política pública estruturada, mas não necessariamente finalizada e entregue para uso no final de 2016.

11 Os 42,3 km de corredores concluídos foram os seguintes: Berrini-trecho 1 (3,3 km), Binário Santo Amaro (8,5 km), Avenida Líder (1,8 km), Luiz Gushiken/Ponte Baixa (3,1 km), requalificação do corredor Inajar de Souza/Rio Branco (14,6 km), M'Boi Mirim (8 km), o prolongamento do corredor Nove de Julho (2,3 km) e Cidade Jardim (0,7 km). Em 2016, existiam corredores próximos do início das obras: Leste Itaquera (12 km) e Chucri Zaidan (2,8 km). Fonte: PMSP, 2016. 
12 Vale ressaltar o caráter binário utilizado por alguns órgãos como metodologia de aferição do cumprimento das metas. A crítica a esse modo binário de aferição era justificada pela sua simplificação, uma vez que determinadas metas, em fase final de conclusão, eram aferidas com valor zero por não ter sido $100 \%$ concluída.

13 Os corredores Aricanduva (14 km), Capão Redondo/Campo Limpo/Vila Sônia (12 km), Radial - trecho 2 $(5 \mathrm{~km})$ totalizam $31 \mathrm{~km}$ e estão licitados e licenciados. Já se encontravam contratados os corredores Carlos Caldeira (3,5 km), M’Boi Mirim/Cachoeirinha (6 km), Santo Amaro-OUFL (2,5 km) e Acesso ao Terminal Jardim Ângela $(1 \mathrm{~km})$. Já o corredor Perimetral Bandeirantes (16 km) estava em processo de licitação. Fonte: PMSP, 2016.

${ }^{14}$ Além do PDE, outras importantes revisões foram desenvolvidas e promulgadas como a Lei de Parcelamento, Uso e Ocupação do Solo (LPUOS) e o Código de Obras (COE). Outras leis e planos foram desenvolvidos como a Lei de Alinhamento Viário do Arco Tietê, a Operação Urbana Consorciada Bairros do Tamanduateí (OUCBT) (em aprovação), o Plano Municipal de Mobilidade Urbana, entre outros projetos urbanísticos de menor escala.

15 Diversos equipamentos foram recuperados para o público ou restaurados como o Centro de Esportes Radicais, Parque dos Búfalos (em desenvolvimento), Parque Ribeirão Colônia (em desenvolvimento), Parque 7 Campos, Praça Ulysses Guimarães e o antigo Clube dos Funcionários Públicos do Estado de São Paulo às margens da represa de Guarapiranga que foi adquirido e aberto para o uso da população.

16 A SVP foi criada em 1977 e funcionou até 2001, quando teve seu nome alterado para Secretaria de Infraestrutura Urbana (SIURB) pelo Decreto n 40.335/2001. Hoje, a secretaria é denominada Secretaria de Serviços e Obras (SSO).

${ }^{17}$ A cidade de São Paulo possui atualmente 12 corredores de ônibus administrados pela SP Trans (além de outro geridos pela Empresa Metropolitana de Transportes Urbanos (EMTU) como o corredor metropolitano ABD (São Mateus - Jabaquara e extensão Diadema - São Paulo/Morumbi)). 0 primeiro corredor inaugurado na cidade foi o Paes de Barros, em 1980, pelo Prefeito Reynaldo de Barros (projeto e parte das obras iniciados na gestão anterior, do prefeito Olavo Setúbal). O corredor Santo Amaro - 9 de julho - Centro foi entregue durantes as gestões dos prefeitos Covas e Jânio, utilizando o trólebus como sistema rodante. Em Cruz (2010, p.113), o autor apresenta a cronologia das ações de transporte coletivo por gestão em São Paulo entre 1999 e 2009, ilustrando as inaugurações dos corredores no período.

18 A gestão da prefeita Marta Suplicy conduziu importantes ações que confrontaram a matriz rodoviarista, tanto na questão da mobilidade urbana, como na ativação e democratização dos espaços públicos. A implantação de corredores de ônibus em maior escala - em que pesem as falhas na sua implantação e infraestrutura -, o bilhete único, os Centros de Educação Unificada (CEU) na periferia e o PDE 2004, introduzindo inovações como as Zonas Especiais de Interesse Social (ZEIS), trouxeram importantes avanços para a cidade.

19 Vemos o arquétipo patrimonialista da alocação de recursos públicos em Villaça (2001), Marques (2000; 2003) e em diversos estudos sobre as Operações Urbanas (OUs) e as Consorciadas (OUCs), que retratam a concentração dos investimentos dos CEPACs no perímetro - principal ou expandido - das operações em regiões centrais da cidade.

20 Em Marques (2003, p. 223), o autor analisa a alocação dos investimentos públicos da Secretaria de Vias Públicas (SVP) na cidade de São Paulo de 1975 a 2000. Utilizando uma abordagem com influência do pluralismo e, sobretudo, do neoinstitucionalismo, verifica a existência de diferenças importantes na alocação de recursos dependendo da clivagem ideológico-partidária da coalizão no exercício do mandato. Outra conclusão importante refere-se à alocação dos investimentos públicos no território: com o recorte utilizado pelo autor, constatou "a existência de investimentos precoces nas periferias de São Paulo". Entretanto, pondera que "as áreas de classe alta receberam, no conjunto do período, um volume muito expressivo de investimentos".

21 O Centro Expandido da cidade de São Paulo é uma área delimitada pelo chamado minianel viário, composto pelas marginais Tietê e Pinheiros, mais as avenidas Salim Farah Maluf, Afonso d’Escragnolle Taunay, Bandeirantes, Juntas Provisórias, Presidente Tancredo Neves, Luís Inácio de Anhaia Melo e o Complexo Viário Maria Maluf. Corresponde às Prefeituras Regionais da Lapa e Pinheiros na zona oeste, Sé no centro, Vila Mariana e Ipiranga (parcial) na zona sul e Mooca e Vila Prudente (parcial) na zona leste.

Pós, Rev. Programa Pós-Grad. Arquit. Urban. FAUUSP. São Paulo, v. 25, n. 46, p.12-31, maio-ago 2018 
22 Distritos com renovação completa para LED: Brasilândia, Raposo Tavares, Pedreira, Sapopemba, Jardim Helena, Lajeado, M’Boi Mirim, Guaianases, Iguatemi, Cidade Tiradentes e Perus. Distritos com renovação parcial: Ipiranga (Heliópolis), São Luís (Monte Azul) e Jabaquara. Fonte: Secretaria Municipal de Serviços (SES), PMSP, 2016.

23 Em 2013, São Paulo possuía um parque de iluminação de aproximadamente 540 mil pontos. Em 2016, esse número saltou para 590 mil devido a novos investimentos nesse período.

24 Os investimentos para a contenção de cheias foram da ordem de mais de R\$ 3 bilhões. Já o Programa de Redução de Alagamentos (PRA) foi estimado em R\$ 133 milhões. Fonte: SIURB, PMSP, 2016.

25 O Hospital Dia/Rede Hora Certa é uma estrutura hospitalar intermediária entre a Unidade Básica de Saúde (UBS), porta de entrada do sistema SUS no município, e os Hospitais Gerais que tratam de casos de internação e de grande complexidade. Assim, esse equipamento de saúde tem como meta reduzir a demanda de exames de saúde e realizar cirurgias mais simples.

26 Nos casos concluídos, a propriedade da terra foi formalizada nos cartórios. Uma parte dos processos de regularização ainda se encontra em tramitação, necessitando concluir todas as etapas burocráticas.

${ }^{27}$ A lei do PMH foi enviada para a Câmara Municipal de São Paulo (CMSP) em dezembro de 2016 e se encontra na CMSP para apreciação e votação (Projeto de Lei 01-00619/2016).

${ }^{28}$ A PMSP recebeu por meio de parcerias alguns prédios públicos federais que eram do INSS. A opção aventada pela SEHAB seria conduzir o retrofit desses edifícios para utilizá-los posteriormente no programa de locação social

29 Um estudo mais detalhado sobre os investimentos públicos realizados no período será apresentado futuramente.

30 Os dados apresentam ainda pequena variância sobretudo por obras ainda não concluídas em equipamentos e em infraestrutura até dezembro de 2016, que apresentavam empenho ainda não executado (sem nota de empenho) ou outros itens necessitando de dotação orçamentária em 2017 para sua finalização.

${ }^{31}$ Em Ferreira (2017, p. 13), o autor aborda o tema explorando um novo ângulo da questão, indo além do Estado Patrimonialista: traz para o debate o conceito de sociedade patrimonialista. Em outras palavras, o Estado é, na verdade, capturado e instrumentalizado por uma pequena elite da sociedade (paulistana), que usa o setor público e seu "aparato político-administrativo de poder e de governança" para, não só preservar e perpetuar a sua riqueza e privilégios históricos, como também aumentá-los ao longo do tempo, reproduzindo e ampliando a desigualdade social em termos relativos.

32 Como ilustração, a diminuição da velocidade de parte das vias para 40 km/h ("Zonas 40"), mesmo sendo uma medida correta e estando alinhado com as políticas de segurança de trânsito internacionais - Londres e Nova Iorque implementaram zonas ainda mais restritivas de $32 \mathrm{~km} / \mathrm{h}$-, poderiam ter sido introduzidas em período mais alongado e com maior comunicação, permitindo a adaptação da medida por mais tempo pela população.

33 O Modelo das Coalizões de Defesa (MCD) foi desenvolvido por Paul Sabatier em diversas obras como, por exemplo, em Sabatier (2006).

34 Em Haddad (2017, p. 33), o ex-prefeito relata uma audiência em dezembro de 2013 com o ministro do STF Joaquim Barbosa, que teria recebido no mesmo dia Paulo Skaf e seu advogado Ives Gandra Martins. Segundo o relato apresentado, havia uma clara distinção de tratamento, postura e tom, dada pelo ministro em seu desfavor, inclusive tendo o Ministro Barbosa alegado que o IPTU em geral era muito caro, em sua opinião. O ex-prefeito relata o desfecho deste caso: "o pedido de cassação da liminar nos foi negado, fato só revertido no âmbito do Tribunal de Justiça de São Paulo, com larga margem de votos a nosso favor, um ano depois - leite já derramado. Infelizmente, na política, quando a Justiça tarda, ela falha".

${ }^{35}$ A PMSP iniciou o programa Paulista Aberta no dia 18/10/2015. No dia 23/10/2015 o MPE encaminhou multa para a Prefeitura.

36 O TAC assinado entre o MPE e PMSP dizia que a Prefeitura não poderia fechar a avenida por mais de três vezes ao ano. A PMSP, por outro lado, dizia que a política pública da Paulista Aberta/Ruas Abertas não se enquadrava dentro do TAC, por se tratar de política pública para ampliar, de forma continuada, os espaços de lazer na cidade.

37 O relatório da CPI do TCM foi encaminhado para o MPE em 2001. 


\section{REFERÊNCIAS}

BONDUKI, N.; ROLNIK, R. "Periferia da Grande São Paulo: reprodução do espaço como expediente de reprodução da força de trabalho". In: MARICATO, E. (org.). A produção capitalista da casa e da cidade do Brasil industrial. São Paulo: Alfa-Ômega, 1982, p. 117-154. BRASIL. Lei No 12.587, de 03 de janeiro de 2012. Diário Oficial da República Federativa do Brasil, Poder Executivo, Brasília, DF, 04 de jan. de 2012. Seção 1, p. 1.

CÂMARA MUNICIPAL DE SÃO PAULO. Relatório da Comissão Parlamentar de Inquérito do Tribunal de Contas do Município de São Paulo, 2001. Disponível em: http://cmspbdoc.inf.br/iah/fulltext/ relatoriocomis/RELFINVOTORDP08-0027-2001.pdf. Acesso em: 30 nov. 2017.

CRUZ, M. F. Condicionantes metropolitanos para políticas públicas: análise dos transportes coletivos na Região Metropolitana de São Paulo (1999-2009). 2010. 146p. Dissertação (Mestrado em Administração Pública e Governo) - Fundação Getúlio Vargas, São Paulo, 2010. DIÓGENES, Juliana. Problema no TCM é só com um conselheiro, afirma Haddad. O Estado de São Paulo, São Paulo, 15 dez. 2015, São Paulo. Disponível em: https://saopaulo.estadao.com.br/noticias/geral,temos-problemas-recorrentes-com-um-conselheiro-do-tcmdiz-haddad,1811772. Acesso em 2 nov 2017.

FAORO, R. Os donos do poder: formação do patronato político brasileiro. $3^{a}$ edição. Porto Alegre: Editora Globo, 1976. 944p.

FERNANDES, F. Que tipo de república? 2a edição. São Paulo: Globo, 2007. 308p.

FERREIRA, J. S. W. O mito da cidade global: o papel da ideologia na produção do espaço urbano. Petrópolis, RJ: Vozes, 2007. 248 p.

FERREIRA, J. S. W. Memorial de Titulação para FAUUSP. 232p. Faculdade de Arquitetura e Urbanismo, Universidade de São Paulo, São Paulo, 2017.

HADDAD, F. Vivi na pele o que aprendi nos livros. Revista Piauí, Rio de Janeiro, n. 129, p. 2837, 2017.

MARICATO, E. "As ideias fora do lugar e o lugar fora das ideias". In: ARANTES, O.; VAINER, C.; MARICATO, E. A cidade do pensamento único: Desmanchando consensos. Petrópolis, RJ: Vozes, 2000, p. 121-192.

MARICATO, E. Metrópole na periferia do capitalismo: ilegalidade, desigualdade e violência. São Paulo: Hucitec, 1996. 144p.

MARQUES, E. C. Estado e redes sociais: permeabilidade e coesão nas políticas urbanas no Rio de Janeiro. Rio de Janeiro: Editora Revan, 2000. 350p.

MARQUES, E. C. Redes sociais, instituições e atores políticos no governo da cidade de São Paulo. $1^{a}$ edição. São Paulo: Ed. Annablume, 2003. 248p.

MARTín, M. Ministério Público de São Paulo quer a suspensão das ciclovias de Haddad. El País Brasil, São Paulo, 18 mar. 2015. Disponível em: https://brasil.elpais.com/brasil/2015/03/18/ politica/1426715775_941420.html. Acesso em: 02 nov. 2017.

REQUENA, C. O paradigma da fluidez do automóvel: burocracias estatais e mobilidade em São Paulo. 2015. 119p. Dissertação (Mestrado em Ciência Política) - Faculdade de Filosofia, Letras e Ciências Humanas, Universidade de São Paulo, São Paulo, 2015.

SABATIER, P. Policy Change and Learning: An Advocacy Coalition Approach. New York: Routledge, 2006. 304p.

SÃO PAULO (Município). Decreto $n^{\circ} 56.834$, de 24 de fevereiro de 2016. Institui o Plano Municipal de Mobilidade Urbana de São Paulo - PlanMob/SP 2015. Diário Oficial do Município de São Paulo, São Paulo, n 35, p. 1, de 25 de fevereiro de 2016.

SÃO PAULO (Município). Programa de metas 2013-2016. 2013. Disponível em: <http:// www. prefeitura.sp.gov.br/cidade/secretarias/upload/videos/AF_FolhetoProgramaMetas.pdf>. Acesso em: 30 nov. 2017. 
pós- |

Nota do Autor

Este artigo foi desenvolvido em 2017, sendo parte de uma pesquisa acadêmica que analisa as políticas urbanas e habitacionais implementadas pelo Executivo na cidade de São Paulo.

\section{Nota do Editor}

Data de submissão: 01/11/2017

Aprovação: 24/04/2018

Revisão: Gabriel H. Kwak

André Kwak

London School of Economics and Political Science. Londres, Reino Unido. andrefhk@gmail.com 